\title{
O modernismo musical brasileiro revisitado
}

Brazilian musical modernism revisited

Pérola Mathias

\section{O Brasil em uníssono: e leituras sobre música e modernismo Santuza Cambraia Naves Rio de Janeiro: Casa da Palavra, 2013}

O modernismo musical projetado nas elaborações teóricas e críticas de Mário de Andrade ganha uma interpretação preciosa nos escritos de Santuza Cambraia Naves compilados em O Brasil em uníssono: e leituras sobre música e modernismo. O livro reúne artigos escritos pela antropóloga ao longo de sua rica trajetória acadêmica e compõe a coleção Modernismo + 90. Organizada por Eduardo Jardim, professor da PUC-Rio e pesquisador do modernismo e do pensamento estético de Mário de Andrade, a coleção tem como objetivo marcar um período da vida intelectual do Brasil no século XX, o Modernismo, quando se come-

Pérola Mathias é doutoranda do Programa de Pós-Graduação em Sociologia e Antropologia da UFRJ (perolavcm@gmail.com).

Resenha recebida em 30 de junho e aprovada para publicação em 9 de setembro de 2014.

Est. Hist., Rio de faneiro, vol. 27, $n^{o}$ 54, p. 373-376, julho-dezembro de 2014. 


\section{Pérola Mathias}

moram os mais de 90 anos passados desde a Semana de 1922, seu marco inicial. A coleção traz à tona aspectos pouco discutidos sobre o momento, suas obras e autores, além de aspectos históricos, empreendendo uma ampla revisão crítica do movimento que ainda hoje é utilizado como referência para entender e intervir na arte e na cultura do país, além de ser continuamente discutido em âmbito acadêmico.

Formada pelo Museu Nacional da UFRJ e pelo IUPERJ, e professora da PUC-Rio, Santuza Naves faleceu precocemente enquanto preparava o livro aqui resenhado, deixando uma lacuna irreparável nos estudos musicais na área das Ciências Sociais, da qual ela era um dos principais nomes. Santuza foi defensora e teorizadora da importância da música popular e da equivalência de seu status ao da literatura e dos ensaios sociológicos na cultura brasileira.

Entre os artigos escolhidos para compor O Brasil em uníssono: e leituras sobre o modernismo estão um capítulo de $O$ violão azul, tese de doutorado da autora, de 1998, artigos publicados ao longo dos anos 2000 e o não concluído "O Brasil em uníssono", de 2012. A tônica principal do livro está neste texto homônimo, que define que o recorte para a análise do modernismo musical brasileiro enfoca o posicionamento de Mário de Andrade enquanto crítico musical e professor do Conservatório Dramático e Musical de São Paulo.

Santuza Naves, considerando a vida de Mário de Andrade como tendo três fases - a busca pela modernização estético-cultural nos primeiros momentos do modernismo em 1922; a priorização da questão da identidade nacional a partir de 1924; e a defesa da atuação política do artista, a partir de $1933^{1}$-, levantou para sua análise textos escritos por Mário entre os anos 1926 e 1944. Ela demonstra como ele propôs incessantemente que o formalismo estético fosse superado para que houvesse um diálogo da arte com o âmbito social e cultural, conformando uma experiência musical brasileira total. Dois textos de Mário são de fundamental importância na análise: o "Ensaio sobre a música popular brasileira", de 1928, e a "Oração de paraninfo", de 1935.

Nesses quase 20 anos em que atuou como crítico, Mário tentou, primeiro, construir uma identidade nacional e, depois, retomar uma "cultura autêntica". Em ambos os momentos buscava a superação do individualismo e a integração do indivíduo num todo orgânico, num movimento capaz de produzir uma "arte interessada" e uma "música artística" que colocariam a arte brasileira para competir no cenário das nações modernas e desenvolvidas - ponto central do Modernismo brasileiro.

Eduardo Jardim diz na introdução que escreve para o livro que "O Brasil em uníssono" foi o primeiro artigo no qual Santuza Naves dedicou toda a sua atenção à Mário de Andrade, analisando sua crítica musical de forma unívoca: através da busca do próprio Mário por uma unidade entre a dimensão estética e a 
dimensão social na arte. Santuza aponta, contudo, que o "uníssono" da crítica andradiana divergia da carreira multifacetada que ele tivera como poeta, romancista, músico, crítico, pesquisador, folclorista, professor e diretor do Departamento de Cultura de São Paulo.

$\mathrm{O}$ artigo "O Brasil em uníssono" nos dá uma visão transversalizada tanto da obra de Santuza Naves quanto do modernismo musical de Mário de Andrade. Ali ela conseguiu sintetizar muitas das análises que empreendera nos demais artigos que compõem o livro, complementando e dando coerência a seu pensamento. Esses outros artigos são "Um tropical amor do mundo", "Bachianas brasileiras $\mathrm{n}^{\circ}$ 7: de Heitor Villa-Lobos para Gustavo Capanema", "Os regentes do Brasil no período Vargas" e "A canção popular entre Mário e Oswald - releituras do modernismo na década de 1960".

Foi ao se aprofundar no Modernismo nos três primeiros artigos que Santuza Naves encontrou a chave para entender como a música popular brasileira da década de 1960 e seus compositores haviam alcançado equivalência de status com os intelectuais e suas formulações na construção de um "retrato do Brasil". Em "Um tropical amor do mundo", ela mostra como a estética promovida pelo modernismo não se comprometeu totalmente com os ideais de civilização. O modernismo propôs que fossem rejeitadas as contribuições da tradição clássica que excluía as manifestações populares, mas assumiu que essas mesmas manifestações representavam a "alma nacional", devendo ser reelaboradas num processo musical erudito. $\mathrm{O}$ modernismo brasileiro fez uma mediação para que fossem diluídas as barreiras na composição da música que separavam os limites entre o popular e o erudito, a tradição e a inovação, o estético e o social.

Santuza demonstra em "O Brasil em uníssono" e "Bachianas brasileiras $\mathrm{n}^{\circ} 7$ " que Mário de Andrade cunhou uma concepção de cultura que distinguia alta e baixa cultura, assemelhando-se à crítica idealista de cultura autêntica/espúria de Edward Sapir, formulada no mesmo período da década de 1920 nos Estados Unidos por influência de Franz Boas. Na prática, essa concepção se traduzia num programa artístico ao mesmo tempo estético e social que recuperava o esvaziamento provocado pela modernização na organização social.

"Os regentes do Brasil no período Vargas" expande a análise do modernismo musical para além do período seguinte à década de 1920, apontando confluências entre o panorama político da centralizadora e populista ditadura Vargas nos anos 1930 e 1940, as teses unanimistas de Mário e as fases de composição de Heitor Villa-Lobos. Villa-Lobos foi o músico que mais se aproximou da realização do projeto musical andradiano.

Mesmo assinalando que as ideias de Mário de Andrade são constantemente retomadas para compreender as concepções artísticas que sucederam ao Modernismo, Santuza busca particularizar o fenômeno de formação de uma es- 


\section{Pérola Mathias}

tética musical nacionalista. Não podemos saber onde Santuza chegaria no inédito "O Brasil em uníssono", mas sua escrita clara, de frases curtas e sintetizadoras de muitas ideias, nos leva a ter uma compreensão ampla sobre as transformações essenciais ocorridas ao longo de todo o período considerado modernista, sem que o tema abordado seja simplificado.

Baseando-se na filosofia nietzscheana das "Considerações intempestivas", Santuza concebe o tempo e a história de forma não linear. Explora uma mesma base teórica por múltiplos lados e questiona incessantemente suas próprias formulações. Essencialmente, a imbricação no entendimento entre arte e vida a move em sua análise.

Encontro nesses artigos uma incessante sequência de hipóteses sendo postas à prova, formuladas, reformuladas e confirmadas. É nesse sentido que " $\mathrm{O}$ Brasil em uníssono" condensa de forma complexa aquilo que já vinha sendo discutido por ela nos outros artigos.

"Sobre Santuza: uma sensibilidade solar" fecha o livro e sela a importância da professora nas palavras de seus alunos Juliana Jabour, Tatiana Bacal e Fred Coelho. Eles ratificam ali a sensibilidade de Santuza na compreensão de nossa cultura através da música e da "canção crítica".

Nota

1. MORAES, E. J. de. A constituição da ideia de modernidade no modernismo brasileira. Tese (doutorado em Filosofia). Rio de Janeiro, Instituto de Filosofia e Ciências Sociais da UFRJ, 1983. 